This is a self-archived version of an original article. This version may differ from the original in pagination and typographic details.

Author(s): Viirret, Tuija Leena

Title: Dialogicality in teaching process drama : three narratives, three frameworks

Year: 2018

Version: Accepted version (Final draft)

Copyright: @ 2018 Drama Australia.

Rights: In Copyright

Rights url: http://rightsstatements.org/page//nC/1.0/?language=en

Please cite the original version:

Viirret, T. L. (2018). Dialogicality in teaching process drama : three narratives, three frameworks. NJ Drama Australia Journal, 42(1), 51-61. https://doi.org/10.1080/14452294.2018.1482728 


\section{Dialogicality in teaching process drama: three narratives, three}

\section{frameworks}

This case study explores dialogicality in teaching process drama through the narratives and practices of three experienced drama teachers of the Open University. Dialogue is understood here in the context of 'I-Thou' attitude and as the phenomenon of heteroglossia. The analyses of the videotaped reflective interviews with the teachers and process dramas revealed a polyphonic picture of dialogicality in the teaching process, in which juxtapositions of communion and alterity are favoured. These findings may help drama teachers to become more conscious about the challenges and possibilities of generating a fluid and energised dialogicality in process drama.

Keywords: process drama; dialogicality; heteroglossia; narrative analysis; drama teacher

\section{Introduction}

The learning process in applied theatre is reciprocal and cyclical, and 'praxis is built on a circularity of thought, feeling, and action' (Nicholson 2014, 44). Nicholson (2005) stated that, at its best, applied theatre creates an atmosphere in which boundaries between 'self' and 'other' are diminished, allowing a common creation to take shape and become the most valuable aspect. However, this does not happen automatically and depends on the spirit of the situation, which is a consequence of the tone of interactions between the students and the teacher (2005). Dialogicality in these interactions creates an environment in which common creativity can be achieved. Thus, this case study explores dialogicality in the narratives and teaching practices of three drama teachers, using videotaped reflective interviews and process dramas to determine how dialogical pedagogy (i.e., the why) and praxis (i.e., the how) appear and are linked together. The 
aim of the study design is to contribute to Nicholson's $(2014,44)$ call for a reopening of the 'debates about the triangulation of performativity, praxis and embodied pedagogies and to consider how this process of learning [in applied drama] might enable participants to map new possibilities for meaning-making'.

The wider framework for the research was to elaborate on drama teacher's practical theory (i.e. the why and the how) and procedures in the interactional frame of process drama and especially in using teacher in role (TIR) -strategy. Process drama is one genre of applied theatre (or applied drama), in which the purpose is to contribute learning and growth. In general, like the process dramas in this study, it proceeds through phases of drama contract, pretext, fiction—including the varying use of drama strategies - and reflection (Bowell and Heap 2001). In this study the research question aimed to discover, in what ways the drama teachers reflect on and validate dialogicality and its significance in their teaching of process drama. The videotaped process dramas and reflective interviews of the drama teachers formed the data, of which the analyses of the dialogical procedures and thinking were conducted.

Dialogue and dialogicality can be viewed from many perspectives (Märtsin 2011; Linell 2009). In this study, the understanding of dialogue is based on the views of Buber and Bakhtin, as summarised by Linell (2009). Buber (1923, 25-27, 50) explained the I-Thou attitude as 'considering "one's whole being”, which is 'an initiation to the mutual relationship'. Instead of objectifying attitudes of I-It, I-Thou relationships are dialogical and characterised by openness, genuineness, respect and presence (Anderson and Cissna 2012). Buber (1923) stated that, in this kind of encounter, each moment of presence is new, unseen and valuable; it is experienced as a whole, without time, place or duration. At its basis, one cannot be and become human without 'You'. This kind of dialogical attitude is ideal for process drama because it fosters commitment, openness 
for 'living through', cooperation, improvisation and equality among both students and teachers (O’Neill 1995; Taylor and Warner 2006; Freebody 2010).

Bakhtin's $(1984,293)$ conceptualisation suits the drama context well because it supports that ' $[\mathrm{t}] \mathrm{o}$ live means to participate in dialogue' in which 'a person participates wholly and throughout his whole life: with his eyes, lips, hands, soul, spirit, with his whole body and deeds'. However, Bakhtin's wholeness does not focus on attitude but on the factual lifeworld of human beings. According to Lähteenmäki $(2009,68)$, Bakhtin's dialogue takes varying positions and dialectic sets as heteroglossia (raznorečie), which means both 'a dialect or a variant of language or dialect sets' and 'a conflict or dispute of words and thoughts'. Bakhtin (1991) talks about micro dialogues, in which words have at least two competing voices, such as 'loving' and 'ironic'. As Lähteenmäki (2002) stated, dialogical relationships prevail between various positions of meanings as well as between two or more voices within a dialogue. In this way, language is used to illuminate social, interpersonal and interactional functions.

Bakhtin's (1984) psycho-physic dialogue and heteroglossia can be viewed as typical elements of process drama, which is defined by the existence of aesthetic doubling that creates space for playfulness and irony (O’Toole 1992; O’Neill 1995). Bolton (1999) described drama as sharing and living through dramatic experiences for which possible solutions are sought in a collaborative manner. To create and experience different viewpoints, Bakhtin's (1984) varying positions in the use of language 'with whole body and deeds', and O'Neill's (1995) emphasis on the dramatic time and structure of using different conventions provokes juxtapositions and tension. This creates opportunity for heteroglossia, and disputes between two or more voices within a drama. Thus, the double frame of fiction and reality creates the common, doubleconsciousness of the joint play (Boal 1995); for example, a group may laugh within 
their roles as actor-spectators at the tragicomic features of the situation or the roles but not at the people playing these roles.

Linell's (2009) views of dialogue summarise the basis for this study. Basing his thinking on Bakhtin's views, he suggested that dialogue includes three dialogical activities: (1) other-orientedness-including feelings of both commonality and sharedness, and differentness from others, (2) interaction and (3) contextinterdependence. These activities also include aspects of semiotic mediation, and “"meaning-making activities" that are mediated in and through language, words, signs, symbols or concepts' (Linell 2009, 4). Interestingly, incompleteness in dialogue and potential loopholes leave room for understanding different perspectives, and such loopholes can create a dialogical third space of mutual understanding-or misunderstanding (Bakhtin 1984; Linell 2009; Leiman 1998). The third space can be seen as the field of actual meaning-making, and in drama, it combines all created aspects in which meaning is much wider than the sum of its parts (Boal 1995; Østern and Heikkinen 2001; Greenwood 2001). In this way, new perspectives can be found, but third space can also cause drama to flounder and come to a halt.

In the next sections, the study design and methodology, the findings of three drama teachers' dialogicality, conclusions and discussion are presented.

\section{Study design and methodology}

The three drama teachers who participated in this study have taught drama education in different contexts and worked in amateur theatre for many years. To maintain anonymity, the content of the dramas are not explained in detail and the teachers will be addressed here using the Finnish gender-neutral names Aale, Niki and Rae and the 
pronoun 'he'. The participants in the process dramas were adults who were mostly already qualified, working teachers or future teachers and were studying drama education at the Open University in various localities in Finland. The structural frameworks of all three cases were similar: each group had studied drama education from the same curriculum for half a year, and the teacher in each case had taught the group before the studied process drama. The teachers chose the process dramas themselves, taking into consideration the researcher's request to have the TIR -strategy included in their teaching. Thus, the overall structure was the same, but the themes, goals and strategies varied. The duration of both the process dramas and the interviews varied from two to three hours, and these were videotaped by the author during two months in 2012. The teachers read and accepted their summarised narratives about dialogicality, which are presented in this article.

The reflective interviews were treated as experience-centred, structured narratives of the teachers' current teacherhood in process drama and analysed using narrative analysis (Squire 2008; Wells 2011). The conceptions of narratives in an educational context emphasise that experiences, identities and lives are discerned narratively in the human mind, creating meaning and sense (Andrews, Squire and Tamboukou 2008; Connelly and Clandinin 2006; Clandinin and Huber 2002). The stimulated recall setting in the interviews endeavoured to find the bases of teachers' practices and the ways in which they interacted and behaved. Teachers watched their own teaching on video, and they each were asked 'to tell whatever comes to your mind about your choices, acts and observations when you were teaching this process drama'. With this kind of instruction the purpose was to allow them to freely provide explanations of their thoughts, feelings, perceptions and choices during the process. Thus, the value of dialogue emerged implicitly in their narrations. 
The narratives were first analysed based on positioning, as it captures practices and facets of identity and unfolds on three levels of narration: the story and its content and structure (i.e., who talks and acts and how they do this), interaction (i.e., selfpositioning, self-reflexive activities and reciprocity) and the dominant discourses

(Deppermann 2013; Wells 2011). This analysis showed, partly self-evidentally because of the study design, that self-reflexive activities, reciprocity and the content are intrinsically emphasised, but the structure of the story and the dominant discourses are less exposed. In addition, as the teachers had a personal and internalised tone in their narratives and their narrations were congruent with their actual teaching activities, the rare, dominant discourses were interpreted as intrinsic parts of their identity as drama teachers. The main analysis in the narratives focused on the aspects of Buber's I-Thou attitude; Bakhtinian heteroglossia as a variant of language and dispute of words and thoughts; and the use of semiotics in dialogue, including symbols, signs and concepts. The summarised narratives are written on that basis.

The analyses of the videoed process dramas were based on researhcer's observations of the teachers' endeavours to construct and maintain dialogicality within the aforementioned aspects. Each analysis of the participants was conducted in relation to the teacher's activities. Only the Bakhtinian dispute of words and thoughts-usually with open laughter-was more closely studied in the activity of the participants because it was a loophole to another way of understanding.

In the next section, the analyses, which provided a fascinating picture of dialogicality in Aale's, Niki's and Rae's pedagogy, are presented.

\section{Three frames of dialogue: involvement, activity and dramaturgy}


All three teachers paid special attention to the group during the reflective interview; however, they all examined the group from their own points of view. The teachers' actual dialogical styles in their process dramas are described first, focussing on their acts and speech during the drama.

According the researcher's observations from the video, Aale, Niki and Rae had different, personal teaching processes but surprisingly similar dialogical styles in their process dramas. The notable difference in their personal styles was the diversity in dynamism and speed. All of them worked with interest and drive. Their I-Thou attitude appeared in their careful listening to both the groups and individuals when they positioned themselves as part of a group, which was clear in both their spatial and verbal actions. In provoking heteroglossia, they each used a homologous question technique and adjusted their speech or gesture repertoires according the group and the situation. During the process, they added participant proposals for the storyline to their behaviour and storytelling. In teacher-in-role (TIR) situations, they took different stances, such as enthusiasm, indecisiveness or toughness, according to the context and the goal of the drama. During the course of the dramas, there were no loopholes detected that could have caused confusion or difficulty; if something was momentarily unclear, the teacher or the participants fluently clarified the situation. Thus, both during TIR situations and when they did not take on a role, the teachers all used semiotics in dialogue by changing their speech speed and genre and using signs, symbols and various gestures in their behaviour, which invited participants to produce differing interpretations and opinions (i.e., heteroglossia). Shortly described, the teachers' speech and acts to create and sustain a common, dialogical space were visible and audibleand their narrations confirmed these perceptions. 
The following narratives are summaries of dialogicality in Aale's, Niki's and Rae's own narratives of their teacherhood at the time of the studied process dramas. One specific question about the significance of laughter-when it focuses on the events inside the drama but is expressed as a spectator outside of the drama—was answered for each teacher. Additionally, they were asked to identify other ways of conducting process dramas in the future. The studied aspects of dialogicality are marked in the narratives as follows, after the statement: Buber's I-Thou (I-T); Bakhtinian heteroglossia as a variant of language and dispute of words and thoughts $(\mathrm{H})$; and the use of semiotics in dialogue, including symbols, signs and concepts (S). The marks are made both when the teacher tells about the phenomenon or when he is worried about its existence.

\section{Aale: involvement}

The structure of Aale's process drama consisted of various conventions through which the participants could create a story. During the drama, it was noteworthy that the participants exhibited a common sense of humour with open laughter, although the drama itself was serious. Thus, the dialogical heteroglossia, in which laughter takes a two-directional place in meaning-making, was observed. In his narrative, Aale payed attention to the commitment and dynamics of the group, including each participant's actions and the impact of these actions on others. He supported these conditions, fostering a dialogical state. He reflected on his own acts for creating an atmosphere of dialogical space through activity.

\footnotetext{
Ifound stronger commitment and courage in the group than before. In the beginning, I told them about the theme only on a universal level so that the small groups would have the freedom to create the story in a direction meaningful for
} 
them. One group quickly developed a story that highlighted touching issues, while another group was slower. But, it's important that everybody is able to participate. $(I-T)$

During my storytelling, I was a bit unsure if they were interested in the story as they were mostly looking at the floor. At one point, I was probably unclear in giving instructions, because one group brainstormed for a long time. (I-T) And I made a lucky mistake! I forgot to ask one group to show their vision of the woman's motives and so the whole group had the opportunity to create their own story out of that! (H) Before my TIR, I wanted to make the situation clear to ensure that everybody understood. In my TIR, I showed commitment, curiosity and excitement. (I-T) (S) When participants laugh in drama, this is a good signthey can link the situation to their own life situations. They handle the situation like spectators. (H) But, I try to keep myself in the role and not laugh because it might be taken as a sign that I don't believe in the drama. (I-T)

During the drama, one character tried to take the floor for a long time. But, when the discussion flowed from the participant to another, I didn't want to interrupt. (I-T) In her talk, she expressed her dissatisfaction with the whole community. This was kind of dangerous, because it is preferable to accept the others' ideas rather than blunt, like in improvisation theatre. So, I decided to keep an eye on her as she decided what direction she wanted to drive the story. And later, I could, in my TIR, provoke her to release her defending role and to bring out something that drove the plot forward. (I-T) The characters who gave descriptions as eyewitnesses were good because all participants were able to construct the story in their mind's eyes. In the end, one character started to grill me, in TIR, to shoo from their community. It was interesting! And, another character expressed three times that he thought the case was closed. (H) (I-T) 
These utterances were signals to me to end the drama, which I quickly did because many viewpoints had been developed. But, we stayed in the drama for a longer time than I am used to because the group was so involved and created so many interesting details. (H) After ending the drama, it was interesting how it unravelled into laughter when the group realised what kind of entirety they had created. There were many who linked the drama to topical themes, and one can be satisfied with this kind of conversation! I'm satisfied; I feel that the drama touched them and their lives. $(H)$

Except for a few little things, I wouldn't change anything else about it. It had a good rhythm, and the episode with the TIR was especially good because of the vivid discussion and tension - their gazes and positions showed their interest in it. In my way of teaching, I try to maintain focus. In this drama, the structure allowed the group to create various stories. My task was to give all possible space for them to focus on the points that touched them the most to allow them to gain a meaningful experience. $(I-T)(H)$

In Aale's reflection, one interesting point was his attention to the participant who_-in her role_-'expressed her dissatisfaction with the whole community'. Aale seemed to interpret this dissatisfaction as a threat for the drama, referring to the idea of acceptance as a principle of improvisation and probably at the same time to the idea of keeping a good, open atmosphere. As an observer, the situation could be interpreted that the participant's utterances were signs of creating tension and heteroglossia in roles—not a dispute between the selves.

\section{Niki: activity}


Niki's process drama was largely based on improvisation. Therefore, the teacher's main goal was to encourage the group to move the drama forward and to solve the problems the TIR inserted into the drama. Thus, opposing views played a big part in this drama. During the interview, it was found that Niki was especially experienced in improvisation, and this had been his first time teaching this particular process drama. He had not anticipated the group's part in the drama's events. In his narrative, dialogicality appears through his elaboration on the time used, the activities of the participants and himself in the TIR and the group's right to decide the direction of the events in the drama.

In the beginning, I was worried both about the time span and the challenging task that I had given to the group—but my worry was groundless! (I-T) For clarity, I put the hat over my head during my TIR, changed my tone and accent and started by addressing the group as workers. (S) I wanted to get the group with me with shouts like 'we do this together, don't we!' (S) (I-T) I also tried to evoke participants' thoughts about their impact on the situation with my everyday speech and hesitations. I told them about the community rules and strengthened the story with details to help the participants work with their roles. I checked often to make sure the groups had been given enough instruction, but they were doing well. In giving them tasks, I considered how much time I would give to them. (I-T) It was great to notice from their actions that some participants were really inside their roles. One group showed with their gestures that there was something not in order, although they verbally assured me that everything was ok. $(I-T)(H)(S)$ So, I decided that this was a secret I should find out at some point. Later it came to light-creating a new problem to solve! $(H)$ 
I was satisfied that the participants highlighted opposing viewpoints when solving the main problem. And, when they found many creative solutions, I improvised many new, logical points of view that they had to consider while struggling with the problem because the whole idea was that the groups had the power to make decisions. When they turned against my role, I wanted to return it back to them, and I asked them to find a solution that would satisfy them all and to give their reasons for this. $(H)(S)$ It was nice to notice that they were still working on the problem and really supported one another. (I-T)

So, we improvised two dramas with the whole group out of the suggested solutions. In the first one, there was one funny situation, but in my TIR, I changed my laugh to seem as if I was crying. I think that comic features in drama show aspects of real life and provoke the participants to continue with the drama. (S) (H) (I-T) And, when drama handles some kind of problem, it doesn't just stop churning in emotions — through funny situations, different perspectives and exits may be found. (H) In the second solution, the group discovered solidary and flexible solutions; they were really brilliant! One comment was really wonderful: the worker referred to the first solution as a better option, though we had just experienced that it didn't work! I was satisfied that this alternative was clearly different than the first one. (H) And, they worked so well, really putting their souls into the drama, listening to each other and taking into account different opinions; they worked together as an operational community. $(I-T)(H)$

In sum, next time I would probably temporally capsulize the drama a bit. I improvised a lot in my TIR, and I'm satisfied that a lot of things and many issues emerged that were handled with the two proposed solutions. $(S)(H)$ In general, I think that the story and how it is presented and handled with the group is an 
important factor of how easily the participants throw themselves into their roles.

Niki's narrative shows that in the improvised parts of process drama there are a lot of opportunities to use the Bakhtinian dispute of words and thoughts or words and gestures. For instance, the 'secret' was 'a problem with selling outdated sausages while the sellers assured evasively that everything was under control', and the suggested 'solution of the worker' was, 'Let's forget the regulations and keep going on', while in their first improvisation this choice soon ended 'in the shutdown by the police'.

\section{Rae: dramaturgy}

The structure of Rae's process drama was based on dynamic and tensional development around the theme, using several conventions. In his reflection, dialogicality appears in his attention to the relaxed, open and spontaneous atmosphere, which included awareness of unfinalisation. In addition, he emphasised the dramaturgical aspect that is often related to dialogicality. At first, Rae considered the conditions for dialogue.

I always want to start in a way that is safe for the participants so that they can act and react creatively, freely and without stress, no matter what they face. I also want to create an atmosphere of incompleteness. I always ask 'Are you ready to go?' before we start to allow them to ask questions if something is unclear; in this case, they did. (I-T)

In my TIR, I wanted to provoke the group to temper. I was non-dialogical, interrupting others many times, because I wanted to stay in focus and raise the 
stakes, allowing the group to become more unified against the TIR. $(H)(S)$ However, once I had to plead with one character not to leave so that the drama wouldn't collapse! In sum, I try to listen and react, while trying to call the shots at the same time. $(I-T)(S)$

When somebody is touched, I try to give him or her space to talk, or not to talk, but I also subtly try to push forward so that the activity and playfulness doesn't disappear in churning emotions. $(I-T)(H)$ I also like misunderstandings, especially if I create them because these strengthen approval for all kinds of interpretations. (H) And, a good drama teacher is genuinely interested in every character and every utterance. The fictive character must be respected, even when he or she is comic. You can kindly laugh at him or her, although not in fiction. (I-T) Laughter inside the drama feeds the fiction. It also reminds us that this is not true life, although in the fiction it is truth. $(H)(I-T)$

The convention of alternative endings is my favourite because it gives space for the group. $(I-T)(H)$ Using it is also a question of dramaturgy and structure. Sometimes when watching the scenes of small groups, I worry about tension and safety; if others get bored, it affects the atmosphere. It's important that everyone in the group feels that they are seen. Often though, the teacher tries to be nonauthoritarian, his comments are still seen as being more worthy than the participants' views. It would be ideal if all group participants, including the teacher, could express their opinions and have those opinions be treated as equally valuable. (I-T)

I notice that I think a lot about the conditions of dramaturgy, so for me, what the participants or I do serves the entirety. By dramaturgy, I mean structure, arrangement of plot and conventions, and dynamics. With framing, I underpin 
contradictions for future events in drama. I am satisfied with this because

interesting themes emerge. (H) I am always interested in the characters and ideas that groups create, and in this way, my teaching is group-based. (I-T) Storytelling and creating a fictional world fascinates me because it is unpredictable, and you should give space for this. Process drama is a common thing, and it is about creating together and sharing responsibility. $(H)(I-T)$

As Rae himself concluded, his way of teaching drama relies on dramaturgy, in which he includes dynamics. In fact, his attention is constantly split between dramaturgy and a free, equal atmosphere, and he utters his worry about the dynamics of both the group and the drama. These aspects influence each other circularly, and the quality of them forms the conditions for dialogue.

\section{Conclusions}

The Buberian I-Thou stance appeared in all three narratives through the respectful, space-giving, listening and caring attitudes of the teachers. They all explained the attention they paid to mutual understanding of potential or actual situations. Aale and Niki, especially, expressed their joy in the commitment and activity of the participants. They both reflected on the meanings of gestures, symbols and signs used by themselves and the participants and mentioned their delight in surprises, such as Aale's 'lucky mistake' of enabling more space for the group or the creativeness in Niki's group, which caused interesting twists in the drama. Aale's concern regarding one participant's negative is interesting; it seems that the challenging task to keep the open spirit between selves and provoke heteroglossia between roles may get mixed up. In fact, the teachers' considerable control during the course of the dramas and their emphasis of space for the 
participants were remarkable in all the narratives. These shifts from control to freedom they actually showed, and it was the strength of their teaching processes. They had clear views of the frameworks and goals of their process dramas, as when Rae highlighted framing in his narrative. Thus, the paradox of concurrent control and freedom includes aspects of safety and involvement, structure and creativity and dynamics and space.

The Bakhtinian heteroglossia in the varying positions was a joint goal; all three teachers uttered their satisfaction when 'enough' viewpoints emerged during the process dramas. In addition, especially in teacher in role, their own contribution through speech and semiotics to provoke or maintain heteroglossia appeared in their narrations. As a conclusion of Rae's narrative, a skilled dramaturgy with skilled guided group dynamics generates a creative, dialogical space for drama.

Linell (2009) summarised that dialogists have tendencies either to communion or to alterity, or both. Loopholes of misunderstandings can be seen as honouring alterity and vice versa, and loopholes of understandings allow expanded unity. Interestingly, misunderstandings, conflicts and competitions may result in unity when participants struggle for understanding. Bakhtin found that, in dialogue, there are always centripetal forces for unity and centrifugal forces for variety (Lähteenmäki 1998). All three teachers emphasised the significance of loopholes in their storylines in increasing participants' freedom to create. As Dunn (2016) describes, mistakes are portals to discoveries. Additionally, Rae's dramaturgical thinking consisted explicitly of incompleteness, misunderstandings, conflicts and (comm)unity. Regarding laughter at events within the dramas, Aale highlights the spectators'viewpoint, Rae mentions the fictional and real world (i.e., double frame) and Niki raises the desire to go on with the drama. These stances all denote the importance of laughter in linking the events in fiction to the real lives of the participants. Laughter in the double frame as a loophole of 
common understanding is a strong bond in process drama. In these moments, like the 'loving and ironic' or (tragi)comic, fictional or true features of life are commonly understood and strengthen joint creation, unify the group and sometimes help solve serious issues.

The drama teacher's challenge to master control and freedom in the dynamics of the group and the drama offers areas for further study. The narrations of drama teachers in various and challenging teaching contexts would be of interest. Hepplewhite (2015) stated that experienced drama practitioners—like those in this study—are crafted in responsivity and shape their activity alongside cooperative work. Additionally, free narrations about teacherhood and dialogicality in process drama would be interesting; in this study, reflection followed the dialogical dramas with committed participants. The emphasis on student's engagement, inclusiveness, collaboration and the dramatic form were also reported in Wales's (2009) research on drama teachers' subjectivities. The participants' experiences in relation to dialogicality and to laughter in the double frame would also be worth of study, as each of their experiences in drama is unique.

Thus, I-Thou attitude, Bakhtinian heteroglossia in its dimensions of variation and dispute and Linell's expanded notion of communion and alterity were important elements in the dialogicality of the studied drama teachers. In their narrations, community was represented as mutual understanding, open atmosphere, commitment and activity, while alterity was articulated as the importance of incompleteness, varying viewpoints, dramaturgy and the double frame. However, this was sometimes ambivalent and intertwined with dialogicality, creating conditions for the generation of embodied knowledge in drama (Nicholson 2014). A deeper understanding of this mixture of elements is hopefully helpful for future drama teachers when creating their dialogical praxis. 


\section{References}

Anderson, R., and K. N. Cissna. 2012. "Martin Buber. Bearing Witness to an

Experience." In Philosophical Profiles in the Theory of Communication, edited by J.

Hannan, R. J. Bernstein, and J. D. Peters, 127-158. New York: P. Lang.

Andrews, M., C. Squire, and M. Tamboukou. 2008. Doing Narrative Research.

London: Sage.

Bakhtin, M. 1984. Problems of Dostoevsky's Poetics. Translated by C. Emerson.

Minneapolis: University of Minnesota.

Bakhtin, M. 1991. Dostojevskin poetiikan ongelmia [Problemy poetiki Dostojevskogo].

Translated by P. Nieminen and T. Laine. Helsinki: Orient Express.

Boal, A. 1995. The Rainbow of Desire. London: Routledge.

Bolton, G. 1999. Acting in Classroom Drama. A Critical Analysis. Portland, Maine:

Calendar Islands Publishers.

Bowell, P., and B. Heap. 2001. Planning Process Drama. London: David Fulton.

Buber, M. 1923. Minä ja Sinä [I and Thou]. Translated by J. Pietilä 1995. Juva: WSOY. 
Clandinin D. J. and J. Huber. 2002. "Narrative Inquiry: Toward Understanding Life's Artistry." Curriculum Inquiry 32 (2): 161-169. DOI: 10.1111/1467-873X.00220

Connelly, M. F. and D. J. Clandinin. 2006. "Narrative Inquiry”. In Handbook of Complementary Methods in Education Research, edited by J. L Green, G. Camilli, and P. B. Elmore, 477-487. Washington, D. C.: American Educational Research Association.

Deppermann, A. (2013). "Editorial: Positioning in narrative interaction." Narrative inquiry 23 (1): 1-15. DOI: 10.1075/ni.23.1.01dep

Dunn, J. 2016. "Demystifying Process Drama: Exploring the why, what and how." NJ Drama Australia Journal 40 (2): 127-140. DOI: 10.1080/14452294.2016.1276738

Freebody, K. 2010. "Exploring teacher- student interactions and moral reasoning practices in drama classrooms." Research in Drama Education: The Journal of Applied Theatre and Performance 15 (2): 209-225. DOI: 10.1080/13569781003700094

Greenwood, J. 2001. "Within a Third Space." Research in Drama Education: The Journal of Applied Theatre and Performance 6 (2): 193-205. DOI:

$10.1080 / 13569780120070731$ 
Hepplewhite, K. 2015. "The applied theatre practitioner as dialogic hero." Research in Drama Education: The Journal of Applied Theatre and Performance 20 (2): 182-185. DOI: $10.1080 / 13569783.2015 .1021322$

Leiman, M. 1998. "Words as Intersubjective Mediators in Psychotherapeutic Discourse: The Presence of Hidden Voices in Patient Utterances." In Dialogues on Bakhtin: Interdisciplinary Readings, edited by M. Lähteenmäki and H. Dufva, 106-117. University of Jyväskylä: Jyväskylä.

Linell, P. 2009. Rethinking language, mind, and world dialogically: Interactional and contextual theories of human sense-making. Charlotte, NC: Information Age Pub.

Lähteenmäki, M. 1998. “On Dynamics and Stability: Saussure, Voloshinov, and Bakhtin.” In Dialogues on Bakhtin: Interdisciplinary Readings, edited by M. Lähteenmäki and H. Dufva, 52-71. University of Jyväskylä: Jyväskylä.

Lähteenmäki, M. 2002. ’Dialoginen näkökulma kieleen: Mihail Bahtin ja Valentin Vološinov." [“Dialogical viewpoint to language: Mihail Bakhtin and Valentin Vološinov"]. In Kielentutkimuksen klassikoita [The classics of language research], edited by H. Dufva and M. Lähteenmäki, 179-200. Jyväskylän yliopisto: Jyväskylä.

Lähteenmäki, M. 2009. ’Dialogisuuden lähteillä: oppihistoriallinen näkökulma Bahtinin dialogiseen kielikäsitykseen" ["On the sources of dialogicality: The viewpoint of conceptual history to Bakhtin's dialogical theory of language"]. Puhe ja kieli 29 (2): 63-74. https://journal.fi/pk/article/view/4786 
Märtsin, M. 2011. Dialogicality in focus: challenges to theory, method and application. New York: Nova Science Publishers.

Nicholson, H. 2005; 2014. Applied Drama: A gift of theatre. Basingstoke: Palgrave Macmillan.

O’Neill, C. 1995. Drama worlds: A framework for process drama. Portsmouth, New Hampshire: Heinemann.

O'Toole, J. 1992. The process of drama: Negotiating art and meaning. London: Routledge.

Squire, C. 2008. "Experience-Centered and Culturally Oriented Approaches to Narrative", In Doing narrative research, edited by M. Andrews, C. Squire, and M. Tamboukou, 41-63. London: Sage.

Taylor, P. and C. D. Warner. 2006. Structure and Spontaneity. The Process Drama of Cecily O'Neill. Staffordshire: Trentham Books.

Wales, P. 2009. "Positioning the drama teacher: exploring the power of identity in teaching practices." Research in Drama Education: The Journal of Applied Theatre and Performance 14 (2): 261-278. DOI: 10.1080/13569780902868911

Wells, K. 2011. Narrative Inquiry. Oxford: Oxford University Press. 
Østern, A. \& Heikkinen, H. 2001. “The Aesthetic Doubling.” In Nordic Voices. In Drama, Theatre and Education, edited by B. Rasmussen, T. Kjølner, V. Rasmusson, and H. Heikkinen, 110-123. Bergen: IDEA Publications. 